\title{
ORNAMENTAL WILLOWS (SALIX SPP.) FOR ALPINE AND SMALL URBAN GARDENS
}

\author{
by Yulia A. Kuzovkina' ${ }^{1}$ and Martin F. Quigley²
}

\begin{abstract}
The small scale and intimate feel of contemporary urban and suburban gardens require appropriate plant material, especially woody plants with multi-seasonal appeal. Many arctic and alpine willows (Salix spp.) are ideally suited to the rock garden, alpine bed, or small urban garden. Here we evaluate alpine, arctic, and other low-growing species of willows for their horticultural merit and tolerance of U.S. Midwestern climatic and soil conditions. Detailed descriptions of 58 taxa are presented, along with photographic images that can be accessed on the Web (chadwickarboretum. osu.edu). We address taxonomy, phenology, autecology, cultural requirements, and ornamental qualities (size and habit, floral quality, bud and leaf color and shape) of selected species new to the North American market.
\end{abstract}

Key Words. Shrubs; rock garden; horticulture; groundcover; willows; Salix.

Due to their small mature size and wide ecological adaptability, low-growing and dwarf Salix species can be successfully used in small urban spaces, as well as in suburban residential rock and alpine gardens. Medium-sized shrub willows, those 0.5 to $1.5 \mathrm{~m}$ ( 1.7 to $4 \mathrm{ft}$ ) tall at maturity, are also suitable for limited space in confined residential gardens. Willows occupy an insignificant place in most nursery stocks, despite their variability and hardiness. The horticultural literature on Salix is sparse, and descriptions and performance information are not reliable for many willow species. Good photographic images of willow species are also difficult to find.

The small willows described here represent arctic and alpine species as well as low-growing species of temperate zones. Our purpose is to evaluate an array of obscure species available either in the trade or from public and private collections, particularly those in the United States, Great Britain, and Eastern Europe. We assess their ornamental potential for small garden landscape use, assess their performance in the continental conditions of the Midwestern United States, and verify identification and clarify taxonomy at the level of species and cultivar. The present work represents a distillation of literature searches in Salix nomenclature for North America, Europe, and Asia, and includes 3 years of growth data and evaluation of these species in central Ohio (USDA hardiness zones 4/5). Many of the taxa discussed here include species that are not well known outside specialists' collections and have only limited availability. Our hope is to reveal the horticultural potential of under-used small shrub willows, to publicize new willow introductions, and to correct some current errors in species and cultivar names.

\section{MATERIALS AND METHODS}

Between 1999 and 2002, we collected or received approximately 200 willow specimens from American and European (British, Polish, and Russian) nurseries, botanical gardens, and arboreta. These plants were installed in replicated plots at The Ohio State University Chadwick Arboretum and the Waterman Agricultural Research Facility, both in Columbus, Ohio, U.S. Performance data were collected over three growing seasons. Plants received supplemental water during the first year after planting to assist them to establish root systems, but they were not subsequently irrigated. These Salix taxa have been under observation throughout the period of study. The 60 species and cultivars described here have been selected for their relatively low growth habit. The field performance evaluations included growth rates; ornamental qualities; insect and disease resistance; and drought, heat, and cold hardiness.

The greatest challenge was the identification of species because many specimens were misnamed at the germplasm source. In an attempt to clean up some long-standing inaccuracies in Salix nomenclature, we turned to original authorities on taxonomy, including Skvortsov (1999) in Russia and Argus (1997) in Canada. Flora of Japan (Ohwi 1965) and Flora of China (Flora of China Editorial Committee 1994) were consulted in a few cases. The List of Names of Woody Plants (List of Names 2000) was used as the standard for cultivar names.

\section{SYSTEMATICS}

The genus Salix comprises three subgenera. The tree-type species belong to the subgenus Salix, the shrub-type to the subgenus Vetrix Dum., and the most low-growing and prostrate species to the subgenus Chamaetia Nasarov (based on Skvortsov 1999). All species examined here are included in the subgenera Chamaetia or Vetrix.

The subgenus Chamaetia consists of five sections: Chamaetia Dum., Retusae Kerner, Myrtilloides Koehne, Glaucae Pax, and Myrtosalix Kerner, and it is especially rich in dwarf and low-growing or creeping species; many of them 
are true alpine and arctic species. The members of this subgenus are typically well adapted to the extreme conditions of montane highlands and tundra. Low-growing and prostrate species can be found in a few other sections of the subgenus Vetrix. Representatives of sections Arbuscella Seringe, Glabrella Skv., Hastatae Kerner, Helix Dum., Incubaceae Kerer, Lanatae Koehne, Vetrix Dum., Villosae Rouy, and Candidae Schneider are described, as well as hybrid species that crosses section divisions.

\section{ENVIRONMENTAL ADAPTATIONS OF ARCTIC AND ALPINE SALIX}

Many species described here originate in arctic tundra or alpine and subalpine zones of the Northern Hemisphere, areas lying above latitudinal and altitudinal tree lines. Some high alpine areas are even named "zones of dwarf willows" because they are the dominant or the only woody species surviving in this extreme environment.

The natural habitats of alpine and arctic species possess unique temperature, light regimes, and soil conditions. The tundra is characterized by permafrost: frozen, poorly drained subsoils with a limited topsoil layer active only in summer, slow rates of decomposition and nutrient cycling, occasional ice encasement, and extremes of photoperiodicity with long days during summer months and almost complete darkness in winter. In alpine zones, plants often grow on exposed rocks or gravelly slopes with little organic soil, constant physical disturbances caused by strong wind and erosion, and intense solar radiation. The strong ultraviolet light of high mountain areas has a stunting effect on plant growth and produces forms of dwarfing. Conditions are normally arid due to radiation and strong winds drying the soil, and available moisture is confined to fast-running drainages along rocky slopes. Both arctic and alpine regions are characterized by a short vegetative season (in some areas lasting only 6 weeks), extreme diurnal temperature fluctuation, low temperatures in winter, and poorly developed soils.

To survive in these conditions, organisms must be highly adapted, and many plant species have developed a number of morphological and physiological adaptations enabling them to perfectly fit into this environment and to function and reproduce successfully.

Arctic and alpine willows grown under severe conditions are much smaller and do not possess the vigor of their lowland relatives. Many of them exhibit a completely prostrate habit, with their stems and leaves lying parallel to the ground while burying the apical meristems below the soil surface or under the snow. Compact carpet or cushion habit creates microclimates that help to protect the apical meristems against thermal fluctuations and enhances shoot hydration, thereby decreasing susceptibility to winter and storm damage. Small leaves prevent excessive water loss through transpiration. Most arctic and alpine willow species have a typical dichotomy in bud size, in which the uppermost three to six buds on the stem are larger than the rest. These large buds produce generative as well as vegetative shoots. Smaller buds will not open in spring but can be broken from dormancy by unusual environmental conditions; they serve as "insurance" for survival in extreme situations.

The tundra species may spend 7 to 9 months of the year under snow, after which the entire reproductive cycle must be completed within a few months or less. Their phenology is adjusted for growth in short vegetative seasons, and they start to grow as soon as the snow disappears. For example, S. herbacea (dwarf willow) needs only 2 to 3 months to grow and complete its reproductive cycle. The patterns of shoot development among arctic, alpine, and lowland species are different. Free growth [the initiation and elongation of stem units proceed simultaneously (Lanner 1976)] is typical for lowland species and favored by mild conditions. In contrast, predetermined, or fixed growth (a dormant period intervenes between the initiation and elongation of stem units), occurs under severe environmental conditions with a short vegetative season. Fixed growth results in a limited quantity of leaves and cessation of growth in early summer. The smallest species will develop only two to five leaves per stem (e.g., S. herbacea), while others develop 15 to 20 leaves (e.g., S. bicolor, S. reinii), but all leaves are preformed in the buds during the previous fall and in spring they just unfold from the bud.

Other features such as small leathery leaves, reduction of trunk size, and exposure (sometimes stems are located entirely in the substrate, leaving only leaves and catkins on the surface) contribute to species adaptability. Optical properties such as reflectivity of pubescent buds, leaves, stems, and flowers (flower bract and ovary) are typical morphological adaptations of tundra species, helping to modulate daily temperature fluctuations and to reflect radiation, preventing tissue overheating.

For most species, flowering takes place at the same time as the leaves are unfolding. The erect catkins of alpine and tundra species are usually not abundant and are located just below the tip of the previous year's shoots. The inflorescences emerge from preformed flower buds, thus maximizing time for flowering and seed set during the short summer. Typically, anthers of filaments of arctic and alpine species are bright red or purple to attract insect pollinators more effectively.

\section{CULTURAL REQUIREMENTS}

Willow shrubs, in spite of their general adaptability, will reliably establish themselves and retain their characteristic forms only under specific conditions. An understanding of the natural environment in which wild alpine and arctic Salix species live is essential for their successful cultivation. They grow in open places with maximum exposure and where there is little interspecific competition. High light requirements can be easily met if plants are installed on raised, 
totally exposed beds or on terraced slopes. There is no need for alpine houses or scree beds to cultivate willows, as are required for many other alpine plants. Willows thrive in small pockets of leaf mold or other moisture-retentive yet well-drained organic soil. The use of young pot-grown plants with a good root system will improve plant establishment. Mulching, either with organic or nonorganic materials (rocks or pebbles), will benefit species with shallow, widely spreading root systems.

There is evidence that some species prefer specific soil $\mathrm{pH}$ ranges in their regions of origin. Some of them (S. alpina, S. elaeagnos, S. reticulata, S. retusa, S. saxatilis, S. tarraconensis) prefer more basic substrate, while others (S. herbacea, $S$. glauca, S. helvetica) prefer acid soils. However, we grew our test species in a variety of soils and they all appear to be $\mathrm{pH}$ adaptable.

While tolerant of a wide range of soil conditions, most willows also do not require proximity to standing water or a high subterranean water table. The imitation of swamp or bog environment for species typically inhabiting such areas appears not to be necessary. Perhaps it is only in natural low-lying or more temperate ecosystems that in extremely moist conditions willows can avoid competition. For example, S. lapponum, S. rosmarinifolia, S. cinerea and S. pedicellaris are often found growing in saturated ground, but they grew even better in well-drained soil at the collection site. Some species (S. repens, S. purpurea) flourish in dry, sandy soil. Of major importance in garden culture is to help plants become established during early stages of root system formation; later, they should be able to tolerate some periods of drought. Only a combination of hot weather [above $32^{\circ} \mathrm{C}\left(90^{\circ} \mathrm{F}\right.$ ] for prolonged periods, drought, and compacted soils (considered to be too dry because of insufficient pore space to hold water) appears to be detrimental for some alpines with superficial root systems. During periods of drought, plants will require supplemental watering, as in any installed landscape.

Willows benefit significantly from occasional pruning, to prevent unkempt appearance and to stimulate new growth, especially as plants become older. If branches were affected by disease or injured during cold winter, then rigorous pruning into healthy tissue will promote new growth and help to overcome the problem. All species except $S$. variegata have their flower buds located on branches formed the preceding year, so the best time to prune is in early spring or right after flowering (for precocious species). Because the ultimate size of many willows can be limited by coppicing, some naturally large-growing but ornamentally valuable willows such as $S$. elaeagnos can be incorporated into the small garden.

Different crown forms, including weeping, contorted, or arching habits, can be achieved by grafting. Several root stocks, such as $S$. $\times$ smithiana, the hybrid of S. caprea and
S. viminalis, are compatible with many species of ornamental top-graft stock. The most popular grafted cultivars in the United States are S. caprea 'Kilmarnock' (weeping pussywillow), and S. integra 'Hakuro-nishiki' (dappled willow). But many other willows having naturally creeping growth can be grafted onto strong-growing upright willows of variable height, usually from 30 to $170 \mathrm{~cm}$ (12 to 68 in.) (Marczynski 1998).

The phenology, certain morphological features such as dwarfing, and physiological traits such as fixed growth, appear to be under genetic but not environmental control. Species from high attitudes and latitudes continue to follow seasonal patterns similar to the patterns in their natural regions: late budbreak and blossom time in spring, annual defoliation a few weeks or even months earlier than locally adapted species, and prolonged dormancy, up to 7 months for some species. Most arctic and alpine species develop only one generation of new shoots per year, but a few under favorable conditions can have several flushes of growth (elongation of more than one terminal bud per shoot each year).

\section{PHENOLOGY}

Willow phenology is typically as much as 4 to 6 weeks ahead of other woody plants in a given area. They break bud in very early spring, and most willow species bloom and foliate before other woody plants even begin to emerge. Willows often provide the most important early pollen source for bees and other insects. By early summer (early June), many arctic and alpine willows cease all shoot growth; by late summer, leaf senescence has begun; and in SeptemberOctober, they shed foliage.

While the precise timing of phenological development fluctuates from year to year depending on weather conditions, the sequence of the events is consistent. In central Ohio, the first species to leaf out at the end of March are S. brachycarpa, S. crenata, S. glauca, S. retusa, S. serpyllifolia, and S. variegata. At that time, S. caprea, S. rosmarinifolia, and S. $\times$ friesiana are in full bloom. Closer to the middle of April, more species break their leaf buds and start flowering: S. helvetica, S. integra, S. repens, S. purpurea, and S. $\times$ grahamii. At the end of April, S. alpina, S. arbuscula, S. bicolor, S. helvetica, S. reinii, S. subopposita, S. tarraconensis, and $S . \times$ balfourii are in full bloom. At the end of April, the latest species break dormancy (S. coesia, S. lanata, S. lapponum, S. nakamurana, S. pyrenaica, and $S . \times$ ambigua). An appropriate planting of species and cultivars in sequence with one another can provide a long blooming time in the spring garden.

\section{ORNAMENTAL FEATURES AND USES OF LOW-GROWING WILLOWS}

Low-growing Salix species are versatile enough for numerous ornamental applications. They are not "utilitarian shrubs" as are their lowland relatives (for instance, the large 
species used for embankment or riparian stabilization) but rather a specialty plant material.

The principal and most recognizable features of willows are their inflorescences, or catkins. Willows are dioecious and, in general, male plants have showier and more attractive inflorescences than females. However, some species also have attractive female inflorescences (S. pyrenaica, S. variegata).

Many small willows exhibit ornamental qualities year round. The texture of foliage canopies ranges from very fine (S. purpurea) to coarse (S. bicolor, S. reinii). Many species can be grown for their foliage (rather than for spring flowering) and with their early leaf break, they provide the first green color in the spring landscape. In summer, dark green, blue, yellow-green, gray, or intense silvery foliage provides effective contrasts to other plants. Many species retain clean leaves throughout the season, though a few begin to yellow or spot by summer's end.

Even leafless shrubs with bare stems and varying forms of ascending or pendulous habit can add interesting architecture to the garden and contribute substantially to the character and appearance of the rock garden. The potential role of willows in the rock garden has been underestimated: Typically, garden books about alpines list no more than two or three willow species. Prostrate species are ideal for cascading over a wall or to cover edges. Small, upright shrubs can make excellent specimen plants, acting as a centerpiece around which the herbaceous composition can be developed. "Alpine-looking" foliage is a major asset of some species such as $S$. $\times$ balfourii, $S$. helvetica and $S$. lanata. Interesting crown architecture when specimens are only a few years old can impart an ancient or gnarled look, adding a sense of maturity to the young garden.

Low-growing willow species that grow too quickly for rock gardens can be used as accent plants for the perennial border. Many willows effectively combine with other plants as informal hedges, edging material or grouped for a mass effect. They can also be placed individually as specimens in lawns.

Cultivation of the smallest dwarf species requires special attention because overshadowing by larger specimens and weeds could destroy the specimen. Many of them can be planted into troughs and other permanent containers to ensure their survival and improve display. Some truly dwarf species such as $S$. herbacea, S. lindleana, and S. reticulata can be used as miniature plants in model railways gardens. Medium-sized willow species make complementary companions to Calluna and Erica in heather gardens along with other low-growing shrubs such as Pinus mugo and Betula nana. Slow-growing alpine species (S. repens, S. helvetica) are commonly trained as bonsai. Species also having attractive catkins are effective specimens for early spring exhibition.

\section{FUTURE INTRODUCTIONS}

The use of willows in the North American market, and particularly the continental Midwest, can be further extended through introductions of native shrubs to the nursery trade. The potential for development of New World willow species is underscored by the fact that the most of species now used ornamentally have Eurasian origin, and some of them have circumpolar distribution (S. arctica, S. glauca, S. herbacea, S. polaris, and S. reticulata). Only two North American endemic species (S. brachycarpa and S. candida) are currently in popular cultivation. The subgenus Chamaetia should be a major focus for research, and many North American as well as Eurasian representatives should be evaluated for ornamental introduction.

Great variation and polymorphism can be found in any native willow population, which has been a source of much confusion in Salix nomenclature. Therefore, for consistent performance in the trade it is important to use genetically identical plants and to select and propagate specific clones.

\section{CONCLUSION}

Tundra species are often difficult to cultivate in more southerly latitudes; certain factors such as length of vegetative period, photoperiod, and irradiation are difficult to imitate and are serious considerations for plant establishment. However, in our trials in Columbus, Ohio, Salix representatives of arctic as well as alpine floras appear able to adapt to the temperate conditions of the central Midwest, where the milder winters and hot, dry summers did not affect plant survival.

Introduction of alpine species to the North American Midwest will further ecophysiological research of the genus and may provide useful data in the context of potential effects of climate change or global warming in arctic ecosystems. 


\section{APPENDIX: IMAGES AND DESCRIPTIONS}

Images and descriptions of the following taxa may be viewed at the Web site of the Chadwick Arboretum and Learning Garden, Department of Horticulture and Crops Science, The Ohio State University, Columbus, Ohio: www.chadwickarboretum.osu.edu.

\author{
S. alpina Scop. \\ S. $\times$ ambigua Ehrh. \\ S. apoda Trautv. \\ S. arbuscula L. \\ S. arctica Pall \\ S. $\times$ ausserdorferi Hut. \\ S. $\times$ balfourii Linton \\ S. bicolor Ehrh. ex Willd. \\ S. 'Boydii' \\ S. brachycarpa Nutt. 'Blue Fox' \\ S. $\times$ brevipens \\ S. candida Fluegge \\ S. caprea L. 'Kilmarnock' \\ S. cinerea L.'Tricolor' \\ S. coesia Vill. \\ S. crenata Hao \\ S. $\times$ doniana Sm. \\ S. elaeagnos Scop. \\ S. × finnmarchica Willd. \\ S. foetida Schleich.
}

\author{
S. $\times$ friesiana Anderss. \\ S. $\times$ gillotii Camus \\ S. glauca L. \\ S. $\times$ grahamii Borrer. \\ S. helvetica Vill. \\ S. herbacea L. \\ S. hylematica Schneider \\ S. integra Thunb. 'Pendula' \\ S. integra Thunb. 'Hakuro-nishiki' \\ S. lanata L. \\ S. lapponum L. 'Grayii' \\ S. lindleyana Wallich. \\ S. 'Mark Postill' \\ S. myrsinites L. \\ S. nakamurana Koidz. \\ S. nivalis Hooker \\ S. pedicellaris Pursh \\ S. phylicifolia L. \\ S. polaris Whlnb.
}

\section{LITERATURE CITED}

Argus, G.W.1997. Infrageneric Classification of Salix (Salicaceae) in the New World. Systematic Botany Monographs, Vol. 52. American Society of Plant Taxonomists, Laramie, WY. 121 pp.

Argus, G.W., C.L. McJannet, and M.J.Dallwitz. 1999. Salicaceae of the Canadian Arctic Archipelago: Descriptions, Illustrations, Identification, and Information Retrieval, Version 2 Nov. 2000. www.mun.ca/biology/delta/arcticf/.

Ohwi, J. 1965. Salix, pp 297-311. In Flora of Japan. Smithonian Institution, Washington, DC. 1,067 pp.

Flora of China Editorial Board. 1994. Salix, pp. 162-274. In Flora of China, Vol. 4. Missouri Botanical Garden Press, St. Louis, MO.

Lanner, R.M. 1976. Patterns of shoot development in Pinus and their relationship to growth potential, pp 223-243. In Cannell, M.G.R., and F.T.Last (Eds.). Tree Physiology and Yield Improvement. Academic Press, London, UK; New York, NY; San Francisco, CA.
List of Names of Woody Plants. 2000. International Standard. Boomteelt Praktijkonderzoek, Wageningen, The Netherlands. 469 pp.

Marczynski, S. 1998. Top grafting of Salix. IPPS 48:337-341. Skvortsov, A.K. 1999. Willows of Russia and Adjacent Countries. Taxonomical and Geographical Review. Univ. Joensuu Fac. Mathem. And Natru. Sci. Rept. Ser. 39. 307 pp.

Acknowledgments. Salaries and research support provided in part by state and federal funds appropriated to the Ohio Agricultural Research and Development Center, The Ohio State University.

1,2* Department of Horticulture and Crop Science

The Ohio State University

2001 Fyffe Court

Columbus, OH 43210, U.S.

Corresponding author: M.F. Quigley

2uigley.30@osu.edu 
Résumé. La petite échelle et l'intimité des jardins contemporains urbains et de banlieues requièrent du matériel végétal approprié, notamment des plantes ligneuses avec un intérêt multi-saisonnier. Plusieurs espèces de saules arctique et alpin sont idéalement convenables pour les rocailles, les plates-bandes alpines ou les petits jardins urbains. Ici, nous évaluons les espèces à petits déploiement de saule arctique, alpin et autres en regard de leurs mérites horticoles et de leurs tolérances aux conditions de sol et de climat du Midwest américain. Des descriptions détaillées de 58 taxons sont présentés avec des photos qui peuvent être vues via le web (chadwickarboretum.osu.edu). On y retrouve des informations sur la taxonomie, la phénologie, l'auto-écologie, les exigences culturales et les qualités ornementales (dimension, forme, qualité florale, bourgeons, couleur et forme des feuilles) d'espèces sélectionnées nouvelles sur le marché nord-américain.

Zusammenfassung. Der kleine Maßstab und das vertraute Gefühl von zeitgenössischen urbanen und suburbanen Gartenanlagen erfordert geeignetes Pflanzenmaterial, besonders holzige Pflanzen mit einer multisaisonalen Erscheinung. Viele arktische und alpine Weiden passen ideal in Steingärten, alpine Gärten oder kleine Vorgärten. Hier bewerten wir alpine, arktische und andere langsam wachsende Weidenarten für ihren Beitrag zur Standortgestaltung, ihre
Toleranz gegenüber dem Klima und den Bodenbedingungen. Die detaillierten Beschreibungen von 58 Taxa werden zusammen mit Abbildungen hier dargestellt und können unter (chadwickarboretum.osu.edu) im web besucht werden. Wir beschreiben Taxonomie, Phenologie, Autökologie, kulturelle Anforderungen, und ornamentale Qualitäten (Größe und Standort, Blütenqualität, Knospen- und Blattfarbe und Form) der neu für den amerikanischen Markt ausgewählten Arten.

Resumen. La escala pequeña y la sensación de intimidad de los jardines urbanos y suburbanos contemporáneos requieren material de plantas apropiado, especialmente plantas leñosas con apariencia multiestacional. Muchos sauces árticos y alpinos son ideales para jardines rocosos, macizos o pequeños jardines urbanos. Evaluamos diferentes especies de sauces árticos y alpinos de bajo crecimiento por su mérito y tolerancia hortícola de clima del oeste medio y condiciones del suelo. Se presentan descripciones detalladas de cincuenta y ocho taxa, junto con imágenes fotográficas, que pueden ser accesadas en la Web (chadwickarboretum.osu.edu). Se señala taxonomía, fenología, auto ecología, requerimientos culturales y cualidades ornamentales (tamaño y hábito, cualidad floral, color y forma de hojas y yemas) de especies seleccionadas nuevas en el mercado Norte Americano. 